\title{
RESENHA:
}

\section{O mentir verdadeiro}

\author{
Raquel Ribeiro Moreira \\ Universidade Tecnológica Federal do Paraná
}

\begin{abstract}
"a mentira política se instalou em nossos povos quase constitucionalmente e o dano

moral tem sido incalculável, alcançando

zonas muito profundas do nosso ser.

Movemo-nos na mentira com naturalidade."

Octávio Paz
\end{abstract}

$\mathrm{O}$ texto $O$ mentir verdadeiro, de Jean-Jacques Courtine, é uma leitura introdutória do livro A Arte da Mentira Polítical, atribuído à Jonathan Swift. No entanto, essa leitura vem marcada pela concepção política e filosófica de um dos grandes pensadores marxista da atualidade, Jean-Jacques Courtine, o que lhe confere uma densidade e complexidade que se consubstanciam à leitura do texto de Swift. Segundo Baronas, na apresentação do livro, a leitura que Courtine faz do texto originário evidencia que a mentira política não é um fenômeno datado, com cor ideológica e nem com nacionalidade, mas atemporal, não-ideológico e universal. Isso porque ele enxerga, indo além do texto de Swift, que a mentira política tem uma trajetória tão antiga quanto intrincada nas relações de constituição social, o que lhe confere uma função verdadeiramente humana/política.

A Arte da Mentira Política não se trata de um livro, mas da apresentação de um tratado em dois volumes a ser lançado conforme o número de assinaturas, entretanto esses dois volumes nunca apareceram. Segundo Courtine, "uma brochura atribuída a Swift, oferecendo em assinatura um livro inexistente de um autor anônimo: uma arte da mentira política não poderia nascer sob melhores auspícios.”(p.16). Esse panfleto se caracteriza como uma sátira à tradição de governar, em que o autor alegra-se em organizar toda uma sistemática das mentiras políticas, um sistema rigoroso "digno de figurar na Enciclopédia" e de se constituir em elementos indispensáveis na "educação de um belo príncipe."

Nessa esteira, Courtine recapitula a história da política ocidental e mostra que o uso da mentira em política já é referido por Platão, em $A$ República, no qual este compara a aplicação da mentira à sonegação de um médico sobre a verdade, quer dizer, uma mentira salutar e, portanto, moralmente sancionada. Seguindo tal trajetória, percebemo-la em $O$ Príncipe, de Maquiavel, no qual a mentira política ganha função de estado. Ao conceder autonomia à política, Maquiavel operou um corte epistêmico que retirou a ética do núcleo da ciência política e conferiu à mentira um estatuto especial, na medida em que o príncipe tinha o direito de utilizar qualquer meio para alcançar seus fins. Essas duas referências, vistas em Platão e Maquiavel, constituíam a validação clássica da mentira política que, evidentemente, assumiu as mais variadas formas, como

\footnotetext{
${ }^{1}$ SWIFT, Jonathan. A arte da mentira política - precedida pelo texto "O mentir verdadeiro" de COURTINE, Jean-Jacques. Campinas, Ed. Pontes, 2006. Traduzido por Mônica G. Zoppi-Fontana e Roberto Leiser Baronas
} 
as apontadas por Swift, por exemplo, em seu panfleto. Contudo, Courtine verifica que a mentira política assume uma outra reconfiguração na atualidade, colocando-se como imanente ao funcionamento político; o embuste não se atem mais às aplicações das falsidades salutares, mas é parte da práxis política.

Se o texto de Swift se coloca como uma "gramática" da mentira política, com suas taxionomias, regularidades e leis, a leitura de Courtine atualiza a reflexão sobre essa prática, apontando o avultamento e o aviltamento das mentiras políticas. A antiga arte do mentir político é tão atual que deixa desenhar uma grande estabilidade dos costumes políticos. Todavia, aquela taxionomia construída por Swift não antevia os grandes avanços nas construções das falsidades salutares, aquela era apenas um "estado artesanal da dissimulação", com sua difusão oral, sua reserva de verossimilhança e suas prescrições de como melhor enganar o povo para o seu próprio bem. Esta "associação de mentirosos" deu lugar, nos dias atuais, a um "Ministério da verdade totalmente dedicado à fabricação da mentira". As práticas são outras, a velocidade das interrelações e suas complexidades também são outras, e é por isso, então, que Courtine afirma que desde a época de Swift a mentira política fez sua revolução industrial: no século XIX, com o desenvolvimento da imprensa, ela se mecanizou e passou a circular numa rapidez e alcance jamais vistos. Mas, foi ao longo do século XX que a mentira política se transformou em produto e em consumo: "a mentira (...) é eletrônica, instantânea, global; o produto de uma organização racional e de uma estrita divisão de trabalho. $\mathrm{O}$ século $\mathrm{XX}$ foi o da era tecnológica da mentira, em que sua produção alcançou uma escala inimaginável, com as mais diversificadas formas, em todos os setores" (p.20).

Comunga desta reflexão Derrida ${ }^{2}$ que, ao comentar Hannah Arendt, afirma que nas sociedades pré-modernas, de certo modo, a mentira estava ligada à política de maneira convencionalmente aceita no que dizia respeito à diplomacia, à razão de Estado, etc., mas circunscrevia-se no interior de um campo limitado do político por contrato. A mutação moderna da mentira é que esses limites deixaram de existir; a mentira atingiu uma espécie de absoluto incontrolável. Ápice da arte da mentira política, o século XX constituiu a "mentira totalitária", varrendo qualquer resquício de pudor, escrúpulo ou reserva de verdade; aliás, foi além, pois a mentira política chegou a "afetar a natureza mesma da linguagem, a possibilidade mesma de pensar a verdade e de expressa-la com palavras."(p.24) Essa afetação leva Courtine a discorrer quanto ao uso dos efeitos discursivos sobre verdade e falsidade aplicados à União Soviética. Ele adverte, ironicamente, a essa última, sobre as conseqüências do descaso ao tratado de Swift: ambicionar fazer o bem ao povo não implica acreditar nas mentiras que se produzem para circular em seu meio - "trágico erro - a brutalidade da queda foi na medida da enormidade das ambições. A ingratidão dos povos não tem limites." 3 (p.25)

Seguindo suas reflexões, Courtine faz uma diferenciação entre a mentira totalitária e as mentiras democráticas. Segundo ele, estas são pluralistas, não requerem exclusividade, mas co-existem, tolerantemente, com as demais. Nesse sentido, o autor faz uma referência à República Francesa, afirmando ter conseguido a direita, por muito tempo, garantir a exclusividade sobre a mentira política na França. Contudo, o que se pensava ser um privilégio natural da direita, democratizou-se, e passou a co-habitar o discurso da esquerda também. A direita "perdeu o monopólio que exercia sobre a mentira e a esquerda perdeu o monopólio sobre a bondade e a virtude". Reflexão fruto de uma realidade amarga e combalida, Courtine retrata a constituição do quadro político

\footnotetext{
${ }^{2}$ DERRIDA, Jacques. Sob palavra: instantâneos filosóficos. Lisboa: Fim de Século, 2005.

${ }^{3}$ Os usos discursivos da mentira versus o mass media levam a proferimentos como os vistos nos últimos meses: "nunca se mentiu tanto no Brasil"; "nunca se viu tanta corrupção"...
} 
francês na fusão indistinta de idéias/mentiras entre a direita e a esquerda. Desse modo, a mentira democrática, uma versão efêmera, eclética e pós-moderna daquela totalitária, desembaraçou-se de todos os obstáculo morais e espalhou-se por toda a vida pública, ficando muito difícil separar a verdade da mentira. Sarcasticamente, o autor afirma ser este o estado ideal do discurso político, em que ele estará "finalmente livre do fantasma mesmo da verdade, que às vezes assombra ainda como um velho remorso." (p.26)

Fazendo um percurso contrário, Courtine finaliza seu texto discutindo a autoria de "A arte da mentira política". O texto atribuído a Swift na verdade foi escrito por John Arbuthnot, médico da Rainha Anna e autor satírico escocês, que ficou conhecido como o inventor de John Bull, um personagem que encarna para toda a eternidade o estereótipo do caráter nacional britânico. Arbuthnot era um autor discreto, pouco interessado em sua reputação literária, e que por isso publicava frequentemente de forma anônima. A dúvida que resta é a de que se houve realmente um tratado em dois volumes sobre a arte da mentira política, ou isso tudo não passou de uma "sugestão" sarcástica à reflexão.

Aliás, esse é o tom de A Arte da Mentira Política. Courtine afirma ser a sátira a via proposta pelo tratado para denunciar a dissimulação política.

Mais adequada ou não, esta fórmula permite desligar a política de um veio moralista, transparente e ditado pela verdade, aproximando-a, assim, ao que Maquiavel fez quando discerniu a política da religião: "a política é um jogo de paixões e de interesses opostos, no qual a dissimulação constitui uma de suas regras essenciais."(p.27). Jean-Jacques Courtine nos põe que, de modo satírico, A Arte da Mentira Política recobre a lição de Maquiavel: "vejam como eles mentem" - é o que profere um narrador anônimo de uma assinatura imaginária de um tratado inexistente. 